\title{
PROFILE OF PATIENTS RECEIVING TOTAL KNEE ARTHROPLASTY: A CROSS-SECTIONAL STUDY
}

\section{PERFIL DE PACIENTES SUBMETIDOS À ARTROPLASTIA TOTAL DE JOELHO: UM ESTUDO TRANSVERSAL}

\author{
Marcelo José Cortez Bezerra ${ }^{1}$, Igor Magalhães Barbosa ${ }^{2}$, Thales Gonçalves de Sousa ${ }^{2}$, Larissa Meireles Fernandes ${ }^{2}$, \\ Diego Leonardo Menezes Maia ${ }^{2}$, Lucas Meireles Holanda ${ }^{2}$
}

1. Department of Orthopedics and Traumatology, Universidade de Fortaleza (Unifor), Fortaleza, CE, Brazil.

2. Centro Universitário Christus (Unichristus), Fortaleza, CE, Brazil.

\section{ABSTRACT}

Objective: To describe the epidemiological profile, presented deformities, associated comorbidities, and impact on quality of life in patients with knee osteoarthritis. This study was conducted in a philanthropic hospital in Fortaleza from 2014 to 2015. Methods: Data were collected from medical records, epidemiological forms, and by applying the Lequesne index questionnaire, which contains several questions related to pain, discomfort and functional limitation to assess the severity of symptoms. Results: Females were more prevalent (76.7\%), as were patients over 65 years of age (61.6\%) and non-whites (81.6\%). As for comorbidities, $83.3 \%$ had hypertension and $31.7 \%$ had diabetes. Of the total, $76.5 \%$ cases were genu varum, and $23.5 \%$ genu valgum. According to the Lequesne index findings, $61.6 \%$ cases were "extremely severe," and women had higher scores. Conclusion: Females were more prevalent and whites were less prevalent. The most frequent comorbidity was hypertension. Female and elderly patients have more severe disease according to Lequesne index score, and these findings were statistically significant. Level of Evidence II, Prospective Study.

Keywords: Arthroplasty. Knee. Osteoarthritis.

\section{RESUMO}

Objetivo: Descrever o perfil epidemiológico, as deformidades, comorbidades associadas e o impacto sobre a qualidade de vida de pacientes com osteoartrite de joelho. O estudo foi realizado em um hospital filantrópico de Fortaleza, no período de 2014 a 2015. Métodos: A coleta de dados foi realizada a partir de análises de prontuários, uso de formulários epidemiológicos e aplicação do questionário de Lequesne, que tem várias questões sobre dor, desconforto e limitação funcional, para avaliar a gravidade dos sintomas. Resultados: Houve maior prevalência do sexo feminino (76,7\%), de pacientes com mais de 65 anos (61,6\%) e das raças não brancas (81,6\%). Sobre comorbidades, 83,3\% tinham hipertensão arterial, 31,7\% tinham diabetes. Do total, 76,5\% tinham geno varo e $23,5 \%$, geno valgo. De acordo com o questionário de Lequesne, 61,6\% tinham quadro "extremamente grave", sendo as mulheres as que tiveram maior pontuação. Conclusão: O sexo feminino foi o mais prevalente. A raça branca foi a menos prevalente. A comorbidade com maior incidência foi a hipertensão arterial. O sexo feminino e os pacientes mais idosos apresentam maior gravidade da doença, segundo o questionário de Lequesne. Esses achados foram estatisticamente significantes. Nível de Evidência II, Estudo Prospectivo.

Descritores: Artroplastia. Joelho. Osteoartrite.

Citation: Bezerra MJ, Barbosa IM, Sousa TG, Fernandes LM, Maia DL, Holanda LM. Profile of patients receiving total knee arthroplasty: a crosssectional study. Acta Ortop Bras. [online]. 2017;25(5):202-5. Available from URL: http://www.scielo.br/aob.

\section{INTRODUCTION}

The growing number of procedures such as arthroplasty results from a number of factors such as the aging of the population, the increasing prevalence of rheumatoid arthritis, and increased numbers of obese patients. ${ }^{1,2}$ Total knee arthroplasty (TKA) is considered to be among the most successful types of orthopedic surgery, since even after 15 years implant survival exceeds 95\%; furthermore, the improvement in quality of life is very significant. ${ }^{3-5}$

The main cause in most patients who undergo this procedure is osteoarthrosis. ${ }^{6,7}$
Studies suggest that Brazil will have the fifth-largest population on the planet in $2050,{ }^{8}$ indicating that the frequency of TKA may increase over the next 30 years.

In order to understand the patients who undergo TKA to treat osteoarthritis (OA), this study collected Lequesne scores and a variety of data including epidemiological information from all patients with OA who were recommended for surgical treatment at the outpatient orthopedics clinic at Hospital Santa Casa de Misericórdia de Fortaleza.

All authors declare no potential conflict of interest related to this article. 


\section{MATERIALS AND METHODS}

This transversal, descriptive study is based on quantitative data. It was carried out between January 2014 and January 2015 at the Santa Casa de Misericórdia de Fortaleza charity hospital. We included patients with osteoarthritis who were referred for surgical treatment and signed the informed consent form. Exclusion criteria were lack of data in the medical records and non-agreement to sign the informed consent form. The study was approved by the institutional review board under number CAAE 44595315.1.0000.5049. Initially data such as sex, race, origin, diagnosis, and presenting deformity were collected from the patient medical records for analysis. In addition, patients filled out an epidemiological form developed by the researchers (Annex 1) which collected data such as age, profession, smoking and drinking habits, wait time prior to surgery, and associated comorbidities such as hypertension and diabetes mellitus. Next, the Lequesne index questionnaire was applied prior to surgery. This questionnaire assesses pain and functional limitation and classifies patients by score. The severity of the disease in the patient can be classified as follows: "mild" (1-4 points), "moderate" (5-7 points), "severe" (8-10 points), "very severe" (11-13 points) and "extremely severe" ( $\geq 14$ points). (Annex 2 ) For uniform application of the questionnaires, the researchers were trained prior to administration.

The patients were recommended for surgical treatment after physical examination and imaging exams performed by orthopedic physicians and radiologists. At no time during this study did these physicians know the Lequesne index scores for their patients.

The statistical analysis was performed using the IBM SPSS Statistics software, version 20.0.0. A 5\% significance level was adopted, and the chi-square hypothesis test was used to investigate the association between categorical variables and the distribution of the sample. P-values $<0.05$ were considered statistically significant.

\section{RESULTS}

The initial sample consisted of 152 patients; at the end of the study, the sample was reduced to 60 patients with knee OA because of missing information in the medical records and loss to follow-up. Women comprised $76.6 \%$ of the sample and men $23.3 \%$ (Table 1). Women were seen to be more affected according to Lequesne index score $(P=0.034)$. Patients aged over 65 years were $61.6 \%$ of the sample, and $38.3 \%$ were in the $55-65$ age range. Application of Pearson's correlation coefficient showed that this correlation was significant $(P=0.035)$ and the relationship was positive, demonstrating that increased age means higher index scores, and consequently the patient is more seriously affected (Table 2).

As for comorbidities, $83.3 \%$ of the patients had hypertension, $31.7 \%$ had diabetes, and $26.7 \%$ had hypertension and diabetes. Of all the patients with a Lequesne score $>14$ ("extremely severe"), 78.3\% had hypertension and $21.6 \%$ did not (Table 3); $8.3 \%$ had knee OA secondary to rheumatoid arthritis. With regard to alcohol and tobacco use, $20 \%$ of the patients drank alcohol and $16.7 \%$ were smokers. No significant connection was found between these habits and disease severity as measured by the Lequesne scores.

\begin{tabular}{c|c|c|c|c}
\multicolumn{1}{c}{ Table 1. Severity according to sex. } & $\begin{array}{c}\text { Extremely } \\
\text { severe }\end{array}$ & Very severe & Severe & Moderate \\
\hline Total sample & $61.6 \%$ & $30 \%$ & $6.6 \%$ & $1.6 \%$ \\
\hline $\begin{array}{c}\text { Females } \\
\text { P }=0.034\end{array}$ & $53.3 \%$ & $20 \%$ & $1.6 \%$ & $1.6 \%$ \\
\hline Males & $8.3 \%$ & $10 \%$ & $5 \%$ & $0 \%$ \\
\hline
\end{tabular}

Table 2. Severity according to age.
\begin{tabular}{c|c|c|c|c}
\hline $\mathbf{P}=\mathbf{0 . 0 3 5}$ & Extremely severe & Very severe & Severe & Moderate \\
\hline $55-65$ years & $23.3 \%$ & $11.66 \%$ & $3.3 \%$ & $0 \%$ \\
\hline$>65$ years & $38.33 \%$ & $18.33 \%$ & $3.3 \%$ & $1.6 \%$ \\
\hline
\end{tabular}

\begin{tabular}{c|c|c|c}
\hline & Table 3. Comorbidities and disease severity. \\
\hline & Hypertension & Diabetes & $\begin{array}{c}\text { Hypertension } \\
\text { and diabetes }\end{array}$ \\
\hline Total sample & $84.9 \%$ & $31.7 \%$ & $26.7 \%$ \\
\hline Extremely severe & $48.3 \%$ & $23.3 \%$ & $18.3 \%$ \\
\hline Very severe & $28.3 \%$ & $6.7 \%$ & $6.7 \%$ \\
\hline Severe & $6.7 \%$ & $1.7 \%$ & $1.7 \%$ \\
\hline Moderate & $1.6 \%$ & $0 \%$ & $0 \%$ \\
\hline \multicolumn{4}{|c}{}
\end{tabular}

Of the total, $76.5 \%$ of cases were genu varum and $23.5 \%$ genu valgum. According to the Lequesne index, $61.6 \%$ of the cases were classified as "extremely severe," $30 \%$ as "very severe," $6.6 \%$ as "severe," and $1.6 \%$ (only one patient) as "moderate." All patients who had OA secondary to rheumatoid arthritis had very high scores, such as 21 points. The highest patient score was 23 points, the lowest score was 7 , and the average was 15.53. We also obtained information about wait time for each patient prior to surgery, which ranged from $<1$ year for $15 \%$ of patients and $1-5$ years for $81.6 \%$ of patients to $>5$ years for $3.3 \%$ of patients.

\section{DISCUSSION}

Many Brazilian studies involving patients who received TKA have found a high prevalence of female patients with an average age ranging from 69 to 79 years. ${ }^{6,9,10}$ As for race, the studies in Brazil are limited. International studies have found that non-whites (namely mixed-race people of African descent and Blacks) have more functional limitation due to $O A$, and non-white women are two times more likely to have knee OA. ${ }^{11-13}$ The present study found a greater prevalence of females $(76.7 \%)$, patients over age 65 (61.6\%), and non-white patients (81.6\%), which is in line with most international studies. However, the Lequesne scores did not show that nonwhite patients were more affected than whites. The Lequesne questionnaire confirmed that women are more affected $(P<0.05)$; $95.6 \%$ of the women were classified as having extremely severe or very severe cases. Furthermore, the Lequesne index showed that older patients were more severely affected $(P<0.05)$.

Some comorbidities such as hypertension and diabetes were frequently present in patients in this study. The use of NSAIDs by a number of patients with OA may have elevated blood pressure. ${ }^{14}$ Furthermore, both hypertension and diabetes are described as having an impact in the pathophysiology of OA, and diabetes is currently considered a risk factor for progression of knee OA. ${ }^{15}$ Hypertension was the most frequent comorbidity, in $83.3 \%$ of the sample, followed by diabetes. Previous studies conducted in Brazil found a lower prevalence of hypertension, ranging from $59 \%$ to $81 \%$, and diabetes ranging from $19 \%$ to $35 \%$. $^{6,9,16}$

Some international studies have described alcohol consumption as often relieving symptoms in patients with $\mathrm{OA}$, but we are very familiar with the risks of this habit in the population in general. ${ }^{17}$ Moreover, recent studies have shown that drinking alcoholic beverages such as beer increases the risk of osteoarthritis. ${ }^{18}$ The current study found alcohol consumption in $20 \%$ of the sample. Perhaps the fact that most of the sample was female influenced this finding, since the female population is known to drink less alcohol than men. In order to confirm whether there was any relationship between drinking alcohol and the severity of OA, patients who consumed alcohol were correlated with Lequesne scores, but the outcome was not statistically significant $(P>0.05)$. 
Some years ago there were some doubts about the effects of cigarette smoking on patients with $\mathrm{OA}$, but a recent meta-analysis showed that smoking did not have a protective effect..$^{19}$ In our study, the prevalence of smokers was low (16.7\%).

Recent studies show that bow-leggedness increases the incidence of OA and increases the progression of medial OA, so an increased prevalence of genu varum is expected in patients with $\mathrm{OA}$ of the knee. ${ }^{20}$ In the present study, more than $75 \%$ of the patients had the genu varum deformity.

The Lequesne questionnaire was developed in France in the 1970s and updated in 2003; it is used often in Europe and contains several questions for patients to answer about pain, discomfort and function, evaluating the severity of symptoms and degree of physical handicap. ${ }^{21}$ The Lequesne index, unlike other questionnaires, is quick and easy to apply, and non-subjective. It does not contain questions specific to the population of a given country and can therefore be used in any population. It is intended for patients with $\mathrm{OA}$, and is brief, so responding is not difficult. Furthermore, it is difficult for patients to manipulate their score for their own benefit on this questionnaire, since they do not know which type of response has a higher point value.
Of the total sample, $61.6 \%$ of cases were classified as "extremely severe" with a score $>14$. Of the total, $30 \%$ of the sample was considered "very severe," $6.6 \%$ "severe," and 1.6\% "moderate." The mean score was 15.53. The high score is consistent, because all these patients were referred for surgical treatment. Other patients with very high scores had rheumatoid arthritis as well as $\mathrm{OA}$, and comprised $8.3 \%$ of the total.

We also noted that although these patients were more severely affected according to their score, they faced a long wait time for surgery since few slots are available; slightly over $80 \%$ needed to wait $1-5$ years for surgery.

\section{CONCLUSION}

Most patients who seek medical help for this problem are over 65 years of age. Females were more prevalent, and whites were least prevalent. The most frequent comorbidity was hypertension. Lequesne index scores were higher in females and in the older patients in the sample, with statistically significant findings. The Lequesne scores for each patient were consistent with degree of severity recognized by the orthopedists and radiologists who recommended surgical treatment.

AUTHORS' CONTRIBUTIONS: Each author made significant individual contributions to this manuscript. MJCB (0000-0001-8629-5417)* IMB (0000-00020051-7734) ${ }^{\star}$, LMF (0000-0002-9208-5667)* , and TGS (0000-0003-0212-3728)* drafted the manuscript. MJCB performed surgeries and was responsible for outpatient care. IMB, MJCB, LMF, TGS, LMH (0000-0003-2960-9170)*, and DLMM (0000-0002-5679-9566)* followed the patients, collected data, and applied the Lequesne index questionnaire. IMB and MJCB evaluated the data from the statistical analysis. All authors performed the bibliographic research reviewed the manuscript, and contributed to the intellectual concept of the study. ${ }^{*} \mathrm{ORCID}$ (Open Researcher and Contributor ID).

\section{REFERENCES}

1. De Piano LPA, Golmia RP, Scheinberg M. Artroplastia total de quadril e joelho: aspectos clínicos na fase perioperatória. Einstein. 2010;8(3 Pt 1):350-3.

2. Guenther D, Schmidl S, Klatte TO, Widhalm HK, Omar M, Krettek C, et al. Overweight and obesity in hip and knee arthroplasty: Evaluation of 6078 cases. World J Orthop. 2015;6(1):137-44.

3. Matos LFC, Alves ALQ, Sobreiro AL Giordano MN, Albuquerque RSP, Carvalho ACP. Navegação na artroplastia total de joelho. Existe vantagem? Acta Ortop Bras. 2011;19(4):184-8

4. March LM, Barcenilla AL, Cross MJ, Lapsley HM, Parker D, Brooks PM. Costs and outcomes of total hip and knee joint replacement for rheumatoid arthritis. Clin Rheumatol. 2008;27(10):1235-42.

5. Kuo FC, Hsu CH, Chen WS, Wang JW. Total knee arthroplasty in carefully selected patients aged 80 years or older. J Orthop Surg Res. 2014;9:61.

6. Lenza M, Ferraz SB, Viola DCM, Garcia Filho RJ, Cendoroglo Neto M, Ferretti M. Epidemiologia da artroplastia total de quadril e de joelho: estudo transversal. Einstein. 2013;11(2):197-202.

7. Metcalfe D, Watts E, Masters JP, Smith N. Anabolic steroids in patients undergoing total knee arthroplasty. BMJ Open. 2012;2(5). pii: e001435.

8. Miranda GM, Mendes AC, Silva AL. O envelhecimento populacional brasileiro: desafios e consequências sociais atuais e futuras. Rev Bras Geriatr Gerontol. 2016;19(3): 507-19.

9. Santos AC, Biagi AC. Perfil epidemiológico dos pacientes submetidos à artroplastia de joelho do serviço de fisioterapia em hospital público de Santo André-SP. ABCS Health Sci. 2013;38(1):2-7.

10. Rosis RG, Kairalla M, Massabki PS. Osteoartrite: avaliação clínica e epidemiológica de pacientes idosos em instituição de longa permanência. Rev Bras Clin Med. 2010;8(2):101-8.

11. Srikanth VK, Fryer JL, Zhai G, Winzenberg TM, Hosmer D, Jones G. A meta-analysis of sex differences prevalence, incidence and severity of osteoarthritis. Osteoarthritis Cartilage. 2005;13(9):769-81.

12. Jordan JM. An Ongoing Assessment of Osteoarthritis in African Americans and Caucasians in North Carolina: The Johnston County Osteoarthritis Project. Trans Am Clin Climatol Assoc. 2015;126:77-86.

13. Sims EL, Keefe FJ, Kraus VB, Guilak F, Queen RM, Schmitt D. Racial differences in gait mechanics associated with knee osteoarthritis. Aging Clin Exp Res. 2009;21(6):463-9.

14. Mackenzie IS, MacDonald TM. Treatment of osteoarthritis in hypertensive patients. Expert Opin Pharmacother. 2010;11(3):393-403.

15. Eymard F, Parsons C, Edwards MH, Petit-Dop F, Reginster JY, Bruyère O, et al. Diabetes is a risk factor for knee osteoarthritis progression. Osteoarthritis Cartilage. 2015;23(6):851-9.

16. Leite AA, Costa AJG, Lima BAM, Padilha AVL, Albuquerque EC, Marques CDL. Comorbidades em pacientes com osteoartrite: frequência e impacto na dor e na função física. Rev Bras Reumatol. 2011;51(2):118-23.

17. Bradlow A, Mowat AG. Alcohol consumption in arthritic patients: clinical and laboratory studies. Ann Rheum Dis. 1985;44(3):163-8.

18. Muthuri SG, Zhang W, Maciewicz RA, Muir K, Doherty M. Beer and wine consumption and risk of knee or hip osteoarthritis: a case control study. Arthritis Res Ther. 2015;17:23.

19. Hui M, Doherty M, Zhang W. Does smoking protect against osteoarthritis? Meta-analysis of observational studies. Ann Rheum Dis. 2011;70(7):1231-7.

20. Sharma L, Song J, Felson DT, Cahue S, Shamiyeh E, Dunlop DD. The role of knee alignment in disease progression and functional decline in knee osteoarthritis. JAMA. 2001;286(2):188-95..

21. Marx FC, Oliveira LM, Bellinil CG, Ribeirol MCC. Tradução e validação cultural do questionário algofuncional de Lequesne para osteoartrite de joelhos e quadris para a língua portuguesa. Rev Bras Reumatol. 2006;46(4):253-60. 


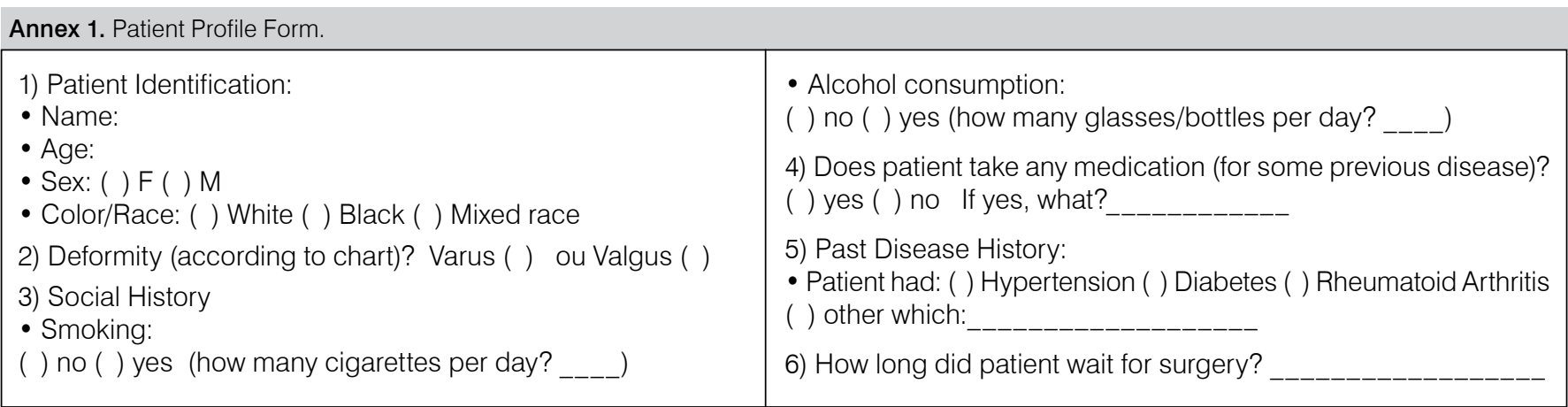

\section{Annex 2. Algofunctional Lequesne Questionnaire}

\section{Pain or Discomfort}

- During sleep at night:

- none or insignificant: 0

- only when moving or in certain positions: 1

- even without movement: 2

- morning stiffness or pain that decreases after getting up

- 1 minute or less: 0

- more than 1 minute, but less than 15 minutes: 1

- more than 15 minutes: 2

- after walking for 30 minutes 0 - 1

- while walking

- none: 0

- only after walking some distance: 1

- soon after beginning to walk, and increases if you continue to walk: 2

- after beginning to walk, not increasing: 1

- when remaining seated for a long time (2 hours) (only if hip) 0 - 1

- when rising from a chair without using the armrests (only if knee) 0 - 1

\section{Maximum distance walked (can walk with pain):}

- unlimited: 0

- more than $1 \mathrm{~km}$, but with some difficulty: 1

- approximately $1 \mathrm{~km}$ (in + or - 15 minutes): 2

- from 500 to 900 meters (approximately 8 to 15 minutes): 3

- from 300 to 500 meters: 4

- from 100 to 300 meters: 5

- less than 100 meters: 6

- with a cane or crutch: 1

- with two crutches or canes: 2

\section{Daily activities/daily life (only applies to knee)*}

- can climb a flight of stairs: $0-2^{*}$

- can go down a flight of stairs: $0-2^{*}$

- squat or kneel: 0 - 2*

- can walk on uneven ground: 0 - 2*

*Without difficulty: 0 , With little difficulty: 0.5 , With difficulty: 1 , With significant difficulty: 1.5, Unable: 2.

\section{Point scoring:}

Extremely severe (greater than or equal to 14 points), Very severe (11 to 13 points), Severe (8 to 10 points), Moderate (5 to 7 points), Mild involvement (1 to 4 points).

Source. Marx FC, Oliveira LM, Bellinil CG, Ribeirol MCC. Tradução e validação cultural do questionário algofuncional de Lequesne para osteoartrite de joelhos e quadris para a língua portuguesa. Rev Bras Reumatol. 2006;46(4):253-60. 